\title{
Differential Display Analysis of cDNA Involved in Microbial Mats Response after Heavy Fuel Oil Contamination
}

\author{
Sylvain Bordenave, Marisol Goni-Urriza, Pierre Caumette, Robert Duran*
}

Université de Pau et des Pays de l'Adour, Institut Pluridisciplinaire de Recherche Environnement et Matériaux - Equipe Environnement et Microbiologie, UMR CNRS 5254 (IPREM - EEM), IBEAS - UFR Sciences et Techniques, BP 1155 F64013 Pau cedex France

\begin{abstract}
Pristine microbial mats from Camargue salterns (France) maintained in microcosm were contaminated by Erika fuel oil in order to identify gene sequences induced in response to heavy fuel oil contamination. The differential display approach was adapted to detect differentially expressed mRNA in complex bacterial communities. Among the six differentially expressed (DD) cDNA fragments isolated, one was identified and associated with an ABC-type efflux pump. A second DD-fragment was related to a conserved hypothetical protein found in many different bacterial species. Despite differentially expressed fragments could not be clearly identified, this study reveals new perspectives for the improvement of our knowledge on the response of microbial community after petroleum contamination.
\end{abstract}

Keywords: Hydrocarbons; Microbial mats; Microcosms; mRNA; Differential display

\section{Introduction}

Bacteria are considered as the main biotic actors in degradation of petroleum products in the environment (Leahy and Colwell, 1990). As single bacterial species is able to degrade a limited number of hydrocarbons, in situ biodegradation of petroleum is usually performed by a consortium composed of many bacterial species. Multiple factors could influence the stability of the bacterial community structure that includes bacterial competition, prophages and physical/chemical conditions.

In coastal zones, particularly exposed to accidental oil spillages and other improper practices, microbial mats develop at the water-sediment interface (Caumette et al., 1994; Van Gemerden, 1993). Ecological success of these bacterial structures and their broad array of microbial activities suggest that they might be useful for bioremediation of environmental pollutants (Bender and Phillips, 2004). Evidence has been presented that microbial mat communities dominated by phototrophic cyanobacteria can be actively involved in the degradation of petroleum and its derivatives (Abed et al., 2006; Bender and Phillips, 2004; Bordenave et al., 2004; Cohen, 2002; Grötzschel et al., 2002; Hoffmann, 1996). In previous study, community analysis based on 16S rRNA (genomic and transcriptomic level) showed clear response of microbial mat after heavy fuel oil contamination [6]. However, analysis of the diversity of genes involved in hydrocarbons biodegradation (dioxygenase and benzyl-succinate synthase) did not show obvious modification after petroleum contamination [6].

One of the major limits for most widespread culture independent methods is their need for a priori information on gene sequence in order to design specific probes or primers. Recently, molecular tools that bypass these prerequisites have been developed and used as new microbiological methods. Fleming and co-workers (Fleming et al., 1998) proposed the DD technique using randomly primed PCR which provides the possibility to assess the specific differences between two RNA populations without previous knowledge of gene sequences revealing thus the unknown part of functional changes. They identified new genes induced by toluene in pure cultures and soils microcosms. DD provides a powerful technique for revealing specific differences between two RNA populations including the unknown part of functional changes in microbial communities.

To clarify the mechanism(s) of the response to heavy fuel oil pollution, analyse of differences in gene expression appears as an accurate approach. The present study aimed to identify genes sequences involved in the microbial mat response to petroleum contamination. Microbial mat used for this work was originated from Camargue salterns (South-East of France) and was contaminated by "Erika" heavy fuel oil (type $\mathrm{n}^{\circ} 2$ ) under microcosm conditions. Because suppressive subtractive hybridization ( $\mathrm{SSH}$ ) method was inefficient to provide information on differentially expressed genes in microbial mat samples (data not shown), we adapted the differential display (DD) method for the analysis of contaminated microbial mats.

\section{Materials and Methods}

\section{Microbial mat sampling and microcosms experiment set up}

Microcosms experiment set up was previously described (Bordenave et al., 2007). Briefly, Camargue microbial mats were collected, stabilized during 1 month and maintained in microcosms. After 15 days of stabilization, 50 to $70 \mathrm{mg} . \mathrm{cm}^{-2}$ of "Erika" heavy fuel oil were added on microbial mat surface of half of the microcosms. These microcosms were used as "contaminated microcosms" and the half leaving as controls. One

*Corresponding author: Robert Duran, Université de Pau et des Pays de l'Adour, Institut Pluridisciplinaire de Recherche Environnement et Matériaux - Equipe Environnement et Microbiologie, UMR CNRS 5254 (IPREM - EEM), IBEAS - UFR Sciences et Techniques, BP 1155 F64013 Pau cedex France, Tel: (33) 5 59407468; Fax: (33) 5 59407494; E-mail: robert.duran@univ-pau.fr

Received December 20, 2009; Accepted December 28, 2009; Published December 28, 2009

Citation: Bordenave S, Goni-Urriza M, Caumette P, Duran R (2009) Differential Display Analysis of cDNA Involved in Microbial Mats Response after Heavy Fuel Oil Contamination. J Microb Biochem Technol Technol 1: 001-004. doi:10.4172/1948-5948.1000001

Copyright: () 2009 Bordenave S, et al. This is an open-access article distributed under the terms of the Creative Commons Attribution License,which permits unrestricted use, distribution, and reproduction in any medium, provided the original author and source are credited. 
control and one contaminated microcosm were taken randomly 6 hours and 90 days after the contamination. From each microbial mat core, 15 to 20 sub samples were collected at different position through the total depth with Pasteur micropipettes (diameter of $6 \mathrm{~mm}$ and depth of $1.5 \mathrm{~cm}$ ) and immediately frozen at $-80^{\circ} \mathrm{C}$.

\section{Differential display}

RNA from microbial mat was extracted as previously described (Bordenave et al., 2007). When indicated, mRNA from total RNA extract was purified using the MICROBExpress ${ }^{\mathrm{TM}}$ bacterial mRNA purification kit (Applied Biosystems/Ambion, Austin USA). The procedure was optimized by combining the provided capture oligo mix with the different MICROBExpress ${ }^{\mathrm{TM}}$ modules (Pseudomonas, Campylobacter, Helicobacter and Rhodobacter). Detection of differential expressed mRNA from contaminated or control microbial mats was completed as described by Fleming et al., (2006) with minor modifications. Briefly, 200 ng of RNA were reverse transcribed using Moloney murine leukemia virus reverse transcriptase (New England Biolabs, Ipswich USA) with $20 \mu \mathrm{M}$ primer 70.3 (ACGGTGCCTG). The cDNA $(5 \mu \mathrm{l})$ were used in differential display PCR. as follow: Taq polymerase (Eurobio, Les Ulis France), $1 \mathrm{U}$; $1.5 \mathrm{mM} \mathrm{MgCl}$; each dNTP, $20 \mu \mathrm{M}$; dimethyl sulfoxide, $6 \%$; $10 \%$ Triton $\mathrm{X}-100,0,1 \%$; primers 70.3 and SD14 (GGGGAACGACGATG), $2 \mu \mathrm{M}$ each; and 1X PCR buffer (Eurobio, Les Ulis France). The amplification was performed in a PTC200 thermal cycler (MJ research, Ramsey USA) by applying 40 cycles consisting of $94^{\circ} \mathrm{C}$ for $30 \mathrm{~s}, 40^{\circ} \mathrm{C}$ for $2 \mathrm{~min}$, and $72^{\circ} \mathrm{C}$ for $1 \mathrm{~min}$, followed by $10 \mathrm{~min}$ final extension step at $72^{\circ} \mathrm{C}$. For each condition, arbitrarily primed reverse transcript PCRs were completed in triplicates using RNA or mRNA-purified extracts from three sub samples. Differentially amplified cDNA were detected by comparing the patterns of RAP-PCR products from the two different conditions on a 5\% (19:1) polyacrylamide gel. Bands of interest were cut and DNA fragments were extracted from gel slices at $37^{\circ} \mathrm{C}$ over night in $180 \mu \mathrm{l}$ of acrylamide elution buffer $(0.5 \mathrm{M}$ ammonium acetate; $10 \mathrm{mM}$ magnesium acetate tetrahydrate; $1 \mathrm{mM}$ EDTA pH8; $0.1 \%$ SDS). After ethanol precipitation DNA was recovered in $10 \mu \mathrm{TE}$ buffer. Purified differentially amplified fragments were reamplified using $0.2 \mu \mathrm{M}$ SD14 and 70.3 primers (Bender and Phillips, 2004) in $50 \mu \mathrm{L}$ PCR reaction mixtures as described above except for a primer annealing at $41^{\circ} \mathrm{C}$ for $1 \mathrm{~min}$. Amplified fragments were cloned (TOPO TA cloning kit, Invitrogen, Cergy Pontoise France) to compensate for the possible background from co-migrating fragments. Cloned products were analyzed by restriction fragment length polymorphism with HaeIII and HinfI. Twenty inserts from each library were analyzed and the main representative pattern (above $80 \%$ ) was sequenced (Big Dye Terminator v 3.1 cycle sequencing kit, Applied Biosystem, Austin USA). Nucleotides sequences were compared to sequences from GenBank DNA database by using the BLAST algorithm (Altschul et al., 1990). The differential expression of fragments was checked by Dot-blot analysis using. DD fragment were ${ }^{32} \mathrm{P}$-labeled by random primer method (Rediprime II DNA Labelling System, GE Healthcare, Aulnay Sous Bois France). Radioactive detection was performed with an imager (Typhoon 9200, GE Healthcare, Aulnay Sous Bois France) after 12 hours of exposition.

\section{Results and Discussion}

Control and contaminated microbial mat microcosms were compared by DD analysis, when conspicuous divergences between the community structures were observed (Bordenave et al., 2007). In a first attend, arbitrarily primed reverse transcript PCR (DD-PCR) was performed on total RNA extract using SD14 and 70.3 primers (Fleming et al., 1998). DD-Fingerprints of triplicate analyses from the different microcosm samples were nearly identical (similarity $>93 \%$ between triplicates). Eighteen differentially amplified gene fragments were detected, among them, fourteen presented homologies with rRNA gene sequences from cultured and uncultured bacteria detected in microbial mats and/or marine environments (data not shown). The others were not related to rRNA genes; one presented homologies with a homoserine deshydrogenase (E-value of $8.10^{-83}$ ) another to a sensor kinase (E-value of $5.10^{-94}$ ) and two could not be related to known sequences. Because verification of rRNA genes differential expression by dot-blotting was improbable, the interpretation of these results remains speculative. Multiple and strenuous quantitative PCR verifications would be needed to

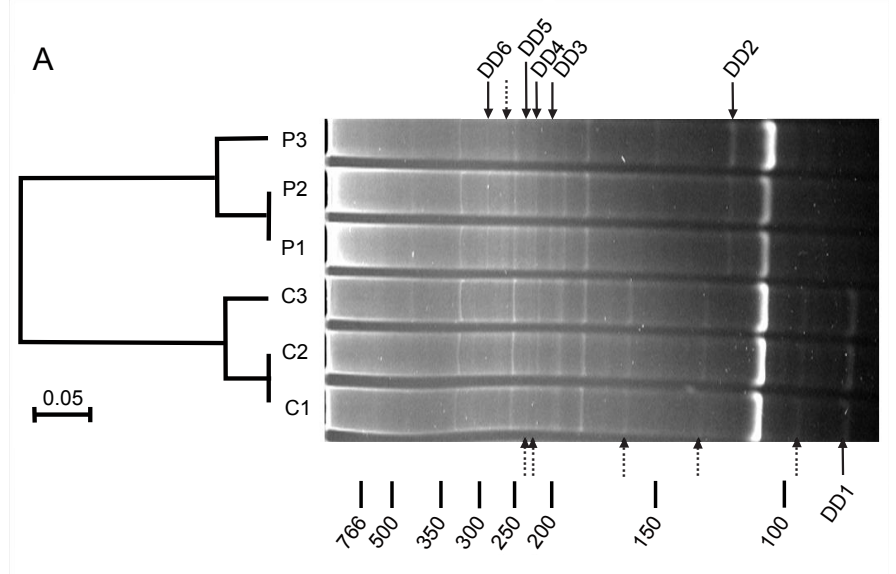

B

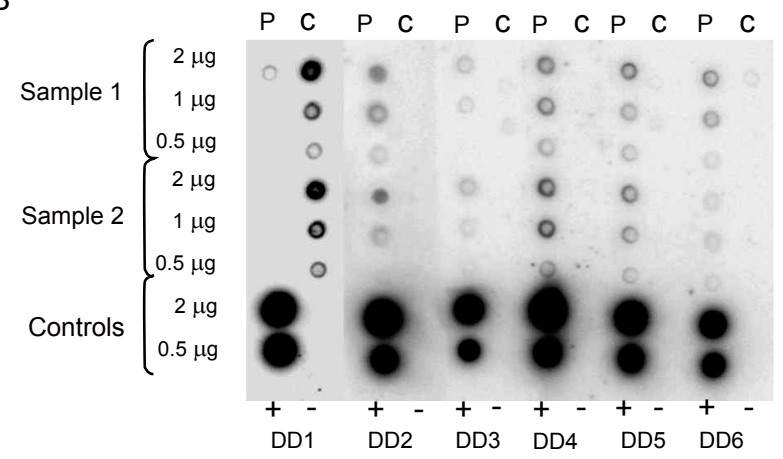

Figure 1: (A) Dendrogram analysis of the polyacrylamide gel banding patterns of DD-PCR products from purified mRNA. Samples C1 to C3 are triplicates from control microbial mat samples after $6 \mathrm{~h}$ of incubation. Samples P1 to P3 are triplicates from polluted microbial mat samples after $6 \mathrm{~h}$ of incubation. Molecular weight standards are represented by ladder below the gel. Dotted arrows indicate differentially amplified fragments that resulted as false positives DD-expressed fragments. Solid arrows indicate the positions of DD-amplified fragments (named as DD1 to DD6) that were confirmed as DD-expressed fragments after (B) dot blot analyses. The names of DD-expressed gene fragments are indicated below the picture. Different quantities $(0.5 \mu \mathrm{g}$ to $2 \mu \mathrm{g})$ of purified mRNA from two control microbial mat (sample 1 and sample 2 in column C) and from two contaminated microbial mat (sample 1 and sample 2 in column P) were blotted. $0.5 \mu \mathrm{g}$ and $2 \mu \mathrm{g}$ of DD-amplified fragment and pool of 16S rRNA encoding genes from Camargue microbial mat were plotted and used as positive (+) and negative (-) controls respectively. 


\section{Journal of Microbial \& Biochemical Technology - Open Access JMBT/Vol.1 Issue 1}

confirm these results. Consistent with previous reports, the abundance of different rRNA limits the access to mRNA (Liang, 2002; Nagel et al., 1999).

In a second attend, the early bacterial response to oil addition was assessed in samples after $6 \mathrm{~h}$ of incubation since previous analyses showed that the active part of the whole bacterial community was modified but not their structure (Bordenave, 2007). To eliminate differences in rRNA bacterial expression, the mRNA was purified using the MICROBExpress ${ }^{\mathrm{TM}}$ bacterial mRNA purification kit (Applied Biosystems/Ambion, Austin USA). Analysis of DD gene expression after mRNA purification from total RNA shows that this step overcomes the problem of rRNA preeminence maintaining the reproducibility ( similarity $>94 \%$ between triplicates, Figure 1A). None of the 12 DD-PCR fragments detected was rRNA gene. The differential expression of 6 of these DD-PCR fragments ( 82 to $279 \mathrm{bp}$ ) was validated by dot blot analyses (Figure 1B).

The few number of DD-genes obtained is in concordance with previous studies (Chang et al., 2004; Li et al., 2006). High proportion of false-positive constitutes one of the limitis of the DD technique and is frequently observed (Liang, 2002; Nagel et al., 1999). Expression of four of the 6 DD-genes was detected only under contamination conditions (Figure 1B, DD2, DD3, DD4, and DD5 bands). The expression of DD1 was 10 times higher in control microcosm compared to the polluted whereas that of DD6 was 15 times higher in polluted microcosms (Figure 1B). Because the bacterial response to oil addition may involve more genes, the use of different primers would be necessary to increase the number of detected DD-genes (Godoy et al., 2007). Homology analyses of the sequenced DNA fragments showed significant hits for two sequences (E-value $<1^{-10}$; Table 1 ). Translated DD5 sequence presented $44 \%$ identity for 76 amino acid residues with an unknown protein of Pelotomaculum thermopropionicum str. SI, a propionate-oxidizing bacteria (Kosaka et al., 2006). Homologues of this protein are found in other microorganisms (Desulfococcus oleovorans $\mathrm{Hxd} 3$, Acidothermus cellulolyticus $11 \mathrm{~B}$ and Chloroflexus aggregans
DSM 9485) and in marine methagenome (Venter et al., 2004). The expression of this protein after petroleum contamination will open new perspectives for the identification of its function by studying the physiology of pure strains. Translated DD3 sequence presented $72 \%$ identity for 61 amino acid residues with an ATPBinding Cassette (ABC)-type $\mathrm{Na}^{+}$efflux pump. Furthermore, DD4 sequence contained specific motifs of signal-peptide and transmembrane region of an $\mathrm{ABC}$ transporter permease (Table 1).

$\mathrm{ABC}$ transporters are involved in the export/import of a wide variety of substrates ranging from small ions to macromolecules. In prokaryotes, the major function of $\mathrm{ABC}$ import systems is to provide essential nutrients to bacteria whereas export systems are involved in the extrusion of noxious substances, the export of extra cellular toxins and the targeting of membrane components (Higgins, 2001). They are involved in resistance to organic solvents (Kim et al., 1998; Tomii and Kanehisa, 1998) and their role in the uptake of hydrocarbons or in the efflux of metabolites especially in PAH-degradation is suggested (Stingley et al., 2004).

Despite bacterial community modification has been previously observed in pristine Camargue microbial mats just after heavy fuel oil contamination (Bordenave et al., 2007), no detectable catabolic response has been reported. Our results reinforce this statement because, among the 6 DD-expressed genes detected, none of them correspond to genes encoding for known catabolicenzymes. The role of these DD genes in the response of petroleum contamination must be characterised and the processes in which they are involved identified. Attribution of a precise function will require isolation of the full-length gene and functional studies of the protein. Most of the previous studies using DD analysis (Chang et al., 2004; Li et al., 2006) have been restricted to pure culture, insensitive to high quantitative proportion of rRNA in nucleic extracts. Because samples from microbial mats contained high levels of rRNA, a mRNA purification step was added without affecting the reproducibility of the method. This metatranscriptomic approach opens new perspectives for the

\begin{tabular}{|c|c|c|c|c|c|c|c|}
\hline $\begin{array}{c}\text { Clone } \\
\left(\text { accession } n^{\circ}\right)\end{array}$ & Condition $^{(a)}$ & Size (bp) & Blast & $\begin{array}{c}\text { Blast result } \\
\text { (accession number) }\end{array}$ & Blast score & E value & $\begin{array}{l}\text { InterProScan } \\
\text { result }\end{array}$ \\
\hline $\begin{array}{c}\text { DD6 } \\
\text { (AM944699) }\end{array}$ & $P$ & 279 & blastx & $\begin{array}{l}\text { acyl-CoA thioester hydrolase } \\
\text { (CP000124) }\end{array}$ & $15 / 24(62 \%)$ & 3.9 & No hit \\
\hline $\begin{array}{c}\text { DD5 } \\
\text { (AM944696) }\end{array}$ & $P$ & 236 & tblastx & $\begin{array}{l}\text { hypothetical protein } \\
\text { (AP009389) }\end{array}$ & $34 / 76(44 \%)$ & $9 . E-11$ & No hit \\
\hline $\begin{array}{c}\text { DD4 } \\
\text { (AM944697) }\end{array}$ & $P$ & 215 & blastn & $\begin{array}{l}\text { ABC transporter permease } \\
\text { (AM039952) }\end{array}$ & 23/24 (95\%) & 6.1 & $\begin{array}{l}\text { signal peptide + } \\
\text { transmembrane } \\
\text { regions }\end{array}$ \\
\hline $\begin{array}{c}\text { DD3 } \\
\text { (AM944695) }\end{array}$ & $P$ & 194 & blastx & $\begin{array}{l}\text { ABC-type } \mathrm{Na}+\text { efflux pump } \\
\text { (AAR36219) }\end{array}$ & $44 / 61(72 \%)$ & 7.E-18 & No hit \\
\hline $\begin{array}{c}\text { DD2 } \\
\text { (AM944698) }\end{array}$ & $\mathrm{P}$ & 105 & blastn & $\begin{array}{l}\text { ABC-type oligopeptide/nickel } \\
\text { transport (AE016827) }\end{array}$ & $25 / 27(92 \%)$ & 0.70 & No hit \\
\hline $\begin{array}{c}\text { DD1 } \\
\text { (AM944700) }\end{array}$ & C & 82 & blastn & $\begin{array}{l}\text { CbbX-like protein, putative AAA } \\
\text { ATPase (CP000271) }\end{array}$ & 26/28 (92\%) & 0.14 & No hit \\
\hline
\end{tabular}

(a) $\mathrm{C}$ for control microbial mat et $\mathrm{P}$ for polluted microbial mat

Table 1: Best Blast scores and protein analysis for the differentially expressed gene fragments from Camargue microbial mat after 6h of incubation (mRNA). 
Citation: Bordenave S, Goni-Urriza M, Caumette P, Duran R (2009) Differential Display Analysis of cDNA Involved in Microbial Mats Response after Heavy Fuel Oil Contamination. J Microb Biochem Technol 1: 001-004. doi:10.4172/1948-5948.1000001

improvement of our knowledge on the bacterial mechanisms involved in response to petroleum contamination.

\section{Acknowledgements}

We acknowledge the financial support by the EC (MATBIOPOL project, grant EVK3-CT-1999-00010 and FACEiT project, grant $\mathrm{N}^{\circ} 018391$ ), the Ministère de l'Ecologie et du Développement Durable (MEDD - LIT'EAU/Erika project, $\mathrm{N}^{\circ} 01 / 1213857$ and PNETOX $\mathrm{N}^{\circ}$ CV04000147) and the ANR (DHYVA project, $\mathrm{N}^{\circ}$ 06SEST09). The authors are grateful to the company of Salins du Midi at Salins-de-Giraud for facilitating access to the salterns, sampling and field experiments. SB was partly supported by a doctoral grant from the Aquitaine region.

\section{References}

1. Abed RMM, Al-Thukair A, De Beer D (2006) Bacterial diversity of a cyanobacterial mat degrading petroleum compounds at elevated salinities and temperatures. FEMS Microbiol Ecol 57: 290-301. »CrossRef » PubMed » Google Scholar

2. Altschul SF, Gish W, Miller W, Myers EW, Lipman DJ (1990) Basic local alignment search tool. J Mol Biol 215: 403-410. » PubMed » Google Scholar

3. Bender $\mathbf{J}$ and Phillips $\mathbf{P}$ (2004) Microbial mats for multiple applications in aquaculture and bioremediation. Bioresour Technol 94: 229-238. »CrossRef » PubMed » Google Scholar

4. Bordenave S (2007) Impact of petroleum contamination on microbial mat and study of their response. PhD Thesis, University of Pau and Pays de l'Adour, Pau, France.

5. Bordenave S, Jézéquel R, Fourçans A, Budzinski H, Merlin FX et al. (2004) Degradation of the "Erika" oil. Aquat Living Resour 17: 261-267. » CrossRef

6. Bordenave S, Goñi-Urriza MS, Caumette P, Duran R (2007) Effects of heavy fuel oil on the bacterial community structure of a pristine microbial mat. Appl Environ Microbiol 73: 6089-6097. »CrossRef » PubMed » Google Scholar

7. Caumette P, Matheron R, Raymond N, Relexans JC (1994) Microbial mats in the hypersaline ponds of Mediterranean salterns (Salins-de-Giraud, France). FEMS Microbiol Ecol 13: 273-286. » Google Scholar

8. Chang IS, Groh JL, Ramsey MM, Ballard JD, Krumholz LR (2004) Differential Expression of Desulfovibrio vulgaris Genes in Response to $\mathrm{Cu}$ (II) and $\mathrm{Hg}(\mathrm{II})$ Toxicity. Appl Environ Microbiol 70: 1847-1851. »CrossRef » PubMed » Google Scholar

9. Cohen Y (2002) Bioremediation of oil by marine microbial mats. Int Microbiol 5: 189-193. » PubMed » Google Scholar

10. Fleming JT, Yao WH, Sayler GS (1998) Optimization of differential display of prokaryotic mRNA: application to pure culture and soil microcosms. Appl Environ Microbiol 64: 3698-706. » CrossRef » PubMed » Google Scholar
11. Godoy APO, Reis FC, Ferraz LFC, Gerrits MM, Mendonça S, et al. (2007) Differentially expressed genes in response to amoxicillin in Helicobacter pylori analyzed by RNA arbitrarily primed PCR. FEMS Immunol Med Microbiol 50: 226-230. » CrossRef » PubMed » Google Scholar

12. Grötzschel S, Köster J, Abed RMM, De Beer D (2002) Degradation of petroleum model compounds immobilized on clay by a hypersaline microbial mat. Biodegradation 13: 273-283. » CrossRef » PubMed » Google Scholar

13. Higgins CF (2001). ABC transporters: Physiology, structure and mechanism - An overview. Res Microbiol 152: 205-210. » PubMed » Google Scholar

14. Hoffmann L (1996) Recolonisation of the intertidal flats by microbial mats after the Gulf War oil spill. In A marine wildlife sanctuary for the Arabian Gulf: environmental research and conservation following the 1991 Gulf War oil spill. Krupp, F., Abuzinada, A.H., and Nader, I.A. (eds). Frankfurt, Germany: Riyad, Saudi Arabia, and Seneckenberg Research Institue pp96-115.

15. Kim K, Lee S, Lee K, Lim D (1998) Isolation and characterization of toluene-sensitive mutants from the toluene-resistant bacterium Pseudomonas putida GM73. J Bacteriol 180: 3692-3696. »CrossRef » PubMed » Google Scholar

16. Kosaka T, Uchiyama T, Ishii SI, Enoki M, Imachi H, et al. (2006) Reconstruction and regulation of the central catabolic pathway in the thermophilic propionate-oxidizing syntroph Pelotomaculum thermopropionicum. J Bacteriol 188: 202-210. »CrossRef » PubMed » Google Scholar

17.Leahy JG, Colwell RR (1990) Microbial degradation of hydrocarbons in the environment. Microbiol Rev 54: 305-15. » CrossRef » PubMed » Google Scholar

18. Li S, Xiao X, Li J, Luo J, Wang F (2006) Identification of genes regulated by changing salinity in the deep-sea bacterium Shewanella sp. WP3 using RNA arbitrarily primed PCR. Extremophiles 10: 97-104. »CrossRef » PubMed » Google Scholar

19.Liang P (2002) A decade of differential display. Biotechniques 33: 338 346. » PubMed » Google Scholar

20. Nagel A, Fleming JT, Sayler GS (1999) Reduction of false positives in prokaryotic mRNA differential display. Biotechniques 26: 641-648. » PubMed » Google Scholar

21. Stingley RL, Khan AA, Cerniglia CE (2004) Molecular characterization of a phenanthrene degradation pathway in Mycobacterium vanbaalenii PYR1. Biochem Biophys Res Commun 322: 133-146. » CrossRef » PubMed » Google Scholar

22. Tomii K, Kanehisa M (1998) A comparative analysis of ABC transporters in complete microbial genomes. Genome Res 8: 1048-1059. »CrossRef » PubMed » Google Scholar

23. Van Gemerden H (1993) Microbial mats : A joint of venture. Marine Geology 113: 3-25. » Google Scholar

24. Venter JC, Remington K, Heidelberg JF, Halpern AL, Rusch D, et al. (2004) Environmental Genome Shotgun Sequencing of the Sargasso Sea. Science 304: 66-74. »CrossRef » PubMed » Google Scholar 